Yüzüncü Y1 Üniversitesi
Tarim Bilimleri Dergisi

Araştırma Makalesi (Research Article)

\title{
Çeşitli Kültür Bitkilerinden İzole Edilen Endofitik Bakterilerin Karakterizasyonu ve Bitki Patojeni Bakterilere Karşı Antagonistik Etkilerinin Belirlenmesi
}

\author{
Yasin BABİER ${ }^{1}$, Ahmet AKKÖPRÜ² \\ ${ }^{1}$ Van Yüzüncü Yıl Üniversitesi, Fen Bilimleri Enstitüsü, Bitki Koruma Bölümü, Van, Türkiye \\ ${ }^{2}$ Van Yüzüncü Yıl Üniversitesi, Ziraat Fakültesi, Bitki Koruma Bölümü, Van, Türkiye \\ ${ }^{1}$ https://orcid.org/0000-0002-6052-4258 ${ }^{2}$ https://orcid.org/0000-0002-1526-6093 \\ *Sorumlu yazar e-posta: ahmetakkopru@yyu.edu.tr
}

\section{Makale Bilgileri}

Geliş: 27.04.2020

Kabul: 07.08.2020

Online Yayınlanma 30.09.2020

DOI: 10.29133/yyutbd.727138

\section{Anahtar kelimeler}

ACC deaminaz,

Antagonizm,

Fosfatı çözündürme,

İndol-3-asetik asit,

PGPR,

Siderofor,

Van.
Öz: Bu çalışmanın amacı çeşitli kültür bitkilerinden izole edilen endofitik bakterilerin (EB) karakterizasyonunu yapmak ve bazı bitki patojeni bakterilere karșı antagonistik etkiye sahip olanlarını belirlemektir. Bu amaçla, Van ili ve civarında yaygın olarak yetiștirilen bazı kültür bitkilerinden fide ve vejetatif dönemde alınan örneklerin yoğun yüzey sterilizasyonuna tabi tutulan kök, gövde, sürgün ve yaprak dokularından 191 endofitik bakteri (EB) izole edilmiştir. Elde edilen bu izolatların PGPR markörlerinden olan; azot fiksasyonu kabiliyeti, fosfatı çözündürme kabiliyeti, aminosiklopropan-1-karboksilat deaminaz (ACC-d) üretimi, indol-3-asetik asit (IAA) üretimi ve siderofor üretimi açısından in-vitro karakterizasyonları yapılmıştır. İzolatların \%58.9'unun gram (-), \%41.1'inin gram (+) olduğu tespit edilmiştir. V33K1, V35Y1, V34G1, V17G2, V30Y3, V38K1, V17K1 ve V36Y2 kodlu EB izolatlarının azot fiksasyonu dışında diğer tüm kategorilerde aktivite gösterdiği tespit edilmiştir. 25 izolat 3 farklı kategoride, 59 izolat 2 farklı kategoride, 67 izolat sadece 1 kategoride aktivite gösterirken, 21 izolat hiçbir kategoride etkinlik gösterememiştir. Ayrıca V30Y3 ve V30G2 kodlu izolatların bitki patojeni 7 farklı bakteri izolatına karşı antagonistik etkiye sahip oldukları belirlenmiştir. Tartılı derecelendirme puanlarına ve antagonistik etkilerine göre seçilen izolatların 16s rDNA dizi analiz sonuçları ile V40K2'nin Bacillus velezensis (MN186863), V30Y3'ün Bacillus megaterium (MN187955), V30G2'nin Pseudomonas caspiana (MN128080), V31Y4'nin Pantoea sp. (MT249279) ve V33K2’nin Bacillus sp. (MT249109) olduğu belirlenmiştir.

\section{Characterization of Endophytic Bacteria Isolated from Various Cultivated Plants and Determination of their Antagonistic Effects on Plant Pathogenic Bacteria}

\section{Article Info}

Received: 27.04.2020 Accepted: 07.08.2020 Online Published 30.09.2020

DOI: $10.29133 /$ yyutbd.727.138
Abstract: This study aims to characterize endophytic bacteria (EB) isolated from various cultivated plants and to identify isolates that have an antagonistic effect against some plant pathogenic bacteria. For this purpose, 191 endophyte bacteria (EB) were isolated from root, stem, shoot, and leaf tissues, which were subjected to intensive surface sterilization of samples taken from seedling and the vegetative period from some cultivated plants widely grown in Van province and its vicinity. In-vitro characterizations of these isolates were made in terms of nitrogen fixation ability, phosphate solubility ability, aminocyclopropane-1-carboxylate deaminase (ACC-d) production ability, indole-3-acetic acid (IAA) production ability and siderophore production ability which are PGPR markers. It was determined that 


\section{Keywords}

ACC deaminase, Antagonisim, Phosphate solubilizing, Indole-3-acetic acid, PGPR,

Siderophore, Van.
$58.9 \%$ of the isolates were gram (-), and $41.1 \%$ were gram (+). It was revealed that EB isolates with codes V33K1, V35Y1, V34G1, V17G2, V30Y3, V38K1, V17K1, and V36Y2 showed activity in all other categories besides nitrogen fixation. Twenty-five isolates were active in 3 different categories, 59 isolates were in 2 different categories, and 67 isolates were active in only one category. In contrast, 21 isolates were not active in any category. It was also determined that isolate V30Y3 and V30G2 had an antagonistic effect against seven different plant pathogenic bacterial isolates. The 16s rDNA sequence analysis of the isolates selected according to weighted grading scores and antagonistic effects identified the isolates with codes V40K2, V30Y3, V30G2, V31Y4, V33K2 as Bacillus velezensis (MN186863), Bacillus megaterium (MN187955), Pseudomonas caspiana (MN128080), Pantoea sp. (MT249279) and Bacillus sp. (MT249109), respectively.

\section{Giriş}

Sürdürülebilir tarım kavramı, üretimde agronomik, çevresel, sosyal ve ekonomik boyutları dengelemeyi hedefleyen bir yaklaşımdır (Turhan, 2005). Entansif tarım uygulamalarının ekosisteme verdiği zararlar düşünüldüğünde, tarımda sürdürülebilir üretim modellerinin geliștirilmesi ve yaygınlaştırılması hayati önem arz etmektedir. Yapılan araştırmalar toprak mikroflorasında, bitki yüzeyinde ve içsel dokularda bulunan birçok mikroorganizmanın bitki gelişimini teşvik edebileceğini veya hastalıkları baskılayarak verim artışı sağlayabileceğini göstermektedir (Hardoim ve ark., 2008; Hardoim, 2011). Bu etkilere sahip ve bitki için olumsuz etkisi olmayan bakteriler "bitki gelişimini teşvik eden rizobakteriler” (Plant Growth Promoting Bacteria-PGPB) olarak ifade edilmektedir.

PGPR üyesi bazı bakteriler bitkilerin içsel dokularında kolonize olabilmektedir. Bunlar Endofitik Bakteriler (EB) olarak adlandırılmaktadır. Birçok tanımı olmakla birlikte genellikle; yüzey dezenfeksiyonu yapılmış bitki dokularından veya bitkilerin iç kısımlarından izole edilebilen, bitkilerin vasküler dokuları ile bitkinin tamamına yayılabilen, konukçuya zarar vermemek suretiyle yaşamının en azından bir bölümünü bitki bünyesinde geçiren mikroorganizmalar olarak tanımlanır (Hallmann ve ark., 1997; Azevedo ve ark., 2000; Rosenblueth ve Martínez-Romero, 2006; Ryan ve ark., 2008; Hardoim ve ark., 2008). EB'in bitkilerdeki yaygınlığının belirlenmesi için yapılan çalışmalarda test edilen tüm bitki türlerinin iç dokularının mikroorganizmalar tarafından kolonize olduğu tespit edilmiștir (Surette ve ark., 2003). EB'ler bitki sağlı̆̆ ve gelişimine PGPR ile benzer mekanizma ve şekilde katk1 sağlayabilirler. Genel olarak PGPB veya EB'ler bitkinin gelişimini veya verimini doğrudan ya da dolaylı olarak etkileyebilmektedir (Saharan ve Nehra, 2011; Pieterse ve ark., 2014). PGPR'lar bitki gelişim hormonlarını üretebilir veya fotosentezi arttırabilirler (Van Loon 2007; Pieterse ve ark., 2014). Bitkideki strese bağlı artan etilen seviyesini azaltarak (Glick, 2014), besin elementlerini bitkinin kullanabileceği forma dönüştürerek ve bitkinin direnç mekanizmalarını uyararak bitkiye direkt olarak katkıda bulunurlar (Antoun ve Prévost 2006; Saharan ve Nehra 2011). Bununla birlikte, antagonizm, rekabet veya savunma sistemlerini uyarma yoluyla bir biyokontrol ajanı olarak hareket edebilir veya faydalı simbiyotik ilişkileri teşvik ederek ya da ksenobiyotikleri etkisizleştirerek bitkiye dolaylı olarak katkı sağlayabilirler (Antoun ve Prévost, 2006; Saharan ve Nehra, 2011).

Yukarıda bahsedilen mekanizmaların yanı sıra diğer epifitik PGPR'lardan farklı olarak EB'ler bitki iç dokularında yaşamalarından dolayı bitkiyle daha yakın bir ilişki kurabilir ve ürettikleri metabolitler bitki tarafından doğrudan algılanabilir. Ayrıca kolonizasyonlarının bitkinin belirli bir bölgesi ile sinırlı olmaması (rizosfer gibi) ve iletim sistemleri yoluyla diğer dokulara taşınmaları patojenlerle her alanda ve birçok mekanizmayla mücadele olanağı sağlamaktadır (Rosenblueth and Martínez-Romero, 2006; Hardoim ve ark., 2008). Diğer yönüyle EB'lerin bitki içinde kolonize olmaları dış ortamda gelişimlerini sınırlandıran biyotik ve abiyotik faktörlerden korunmalarını sağlayabilir ve uzun süre bitkide varlıklarını sürdürmelerine yardımcı olabilir (Rosenblueth ve Martínez-Romero, 2006; Mercado-Blanco ve Lugtenberg, 2014).

$\mathrm{Bu}$ avantajlarından dolayı EB'in tarımsal üretime aktarılma çalışmaları her geçen gün artmaktadır. Bu amaç ile EB'lerin bazı markör özelliklerinin in-vitro testler ile belirlenmesi yolu ile ön seçimleri yapılmaktadır. Bunlar arasında özellikle Azot fikse etme, fosfor alımını kolaylaştırma, 1aminoklopropan-1-karboksilat deaminaz (ACC-d) üretimi, indol-3-asetik asit (IAA) üretimi ve siderofor 
üretimi, hedef patojenlere karşı antagonistik etki gibi bazı karakterler ön plana çıkan bazı özelliklerdir. Ayrıca bu markörlerin in-vitro çalışmalar ile taranması in-vivo çalışmalardaki yüksek maliyet, emek ve zaman kaybını azaltmada çok önemlidir. Böylece bu süreç sonunda in-vivo testlere alınan aday izolatlar içinden hedeflere uygun adayları belirleme şansı arttırılmaktadır.

Yürütülen bu çalışmada Van Gölü Havzasında yaygın olarak yetiştirilen kültür bitkilerinden EB adaylarının izolasyonu, karakterizasyonu ve tanılanması hedeflenmiştir. Elde edilen izolatların azot fikse etme kabiliyetleri, fosfatı çözündürme kabiliyetleri, ACC-d, IAA ve siderofor üretimleri invitro' da araştırılmıştır. Karakterizasyon testlerinin değerlendirilmesi için tartılı derecelendirme yöntemi kullanılmış ve en başarılı bulunan izolatlar bitki patojeni bakterilere karşı antagonistik etkileri in-vitro çalışmalarla belirlenmiştir. Ümitvar bulunan izolatların tanılanması 16s rRNA dizi analizi ile yapılmıştır.

\section{Materyal ve Yöntem}

\subsection{Endofitik bakterilerin izolasyonu}

Endofit bakteriler fide veya vejetatif dönemde olan biber, domates, fasulye, hıyar, kabak, karpuz, kavun, marul, nohut ve patlıcan gibi 10 farklı bitki türünün kök, gövde, sürgün ve yapraklarından izole edilmiştir. EB izolasyonu amaçlı bitki örnekleri 12 Haziran-15 Temmuz 2018 tarihleri arasında Van ili Edremit, Erciş, Gevaş, Muradiye ve Tuşba, ilçelerinde açıkta yetiştiricilik yapılan işletmelerden toplanmıştır (Babier, 2019).

EB izolasyonu yapılacak bitkilerin seçiminde biyotik ve/veya abiyotik stres faktörlerinin görüldüğü yerlerden sağlıklı bitkilerin toplanması yöntemi izlenmiştir (Şekil 1a). Bitki örnekleri, kökleri ve bir miktar toprakla birlikte polietilen torbalara konarak soğuk zincirde laboratuvara getirilmiş ve izolasyon yapılıncaya kadar (maksimum 24 saat) $4^{\circ} \mathrm{C}$ 'de buzdolabında muhafaza edilmiştir.

Musluk suyuyla yıkanarak toprak atıklarından temizlenen bitki örneklerinin kök, gövde, sürgün ve yapraklarında steril bisturi yardımıyla alınan yaklaşık $1 \mathrm{~cm}$ boyutundaki örneklerden izolasyon çalışmaları yapılmışıtır. Örnekler sırasıyla 10 dakika \%2'lik sodyum hipoklorit (NaOCl) ardından 10 dakika \%70'lik etil alkolde bekletilerek yüzey sterilizasyonu gerçekleştirilmiş ve sonrasında steril saf su ile 3'er dakikalık 3 durulama yapılmıştır (Şekil 1b.). Yüzey sterilizasyonu tamamlanan örnekler kurutma kağıtları yardımı ile kurutulduktan sonra steril havan ve havan eli yardımıyla ezilmiş ve 1-2 $\mathrm{mL}$ steril saf su ilave edilmiştir. Elde edilen ekstrakttan $100 \mu \mathrm{L}$ örnek alınıp cycloheximide $(100 \mu \mathrm{g} / \mathrm{L})$ içeren nutrient broth agar (NBA) (Merck) besiyerine steril baget yardımıyla yayılarak ekim yapılmıştır. Aynı miktar son durulama suyundan alınarak besi yerine ekim yapılmış ve örneklerin yüzey sterilizasyonu başarısı kontrol edilmiştir. İnkübasyon periyodunun $\left(25 \pm 2^{\circ} \mathrm{C}-48\right.$ saat $)$ sonunda durulama suyuna ait Petri kaplarında herhangi bir mikrobiyal gelişim gözlenmesi durumunda ait olduğu örneğin sterilizasyonunun başarısız olduğuna karar verilmiş ve örnek elenmiştir.

Yüzey sterilizasyonu başarılı olan örneklerin bulunduğu Petri kaplarında $(7 \mathrm{~cm} \varnothing)$ gelişen bakteri kolonileri; renk, koloni çapı vb. morfolojik özelliklerine göre değerlendirilmiştir. Birbirlerinden farklı olduğu düşünülen koloniler saflaştırılmak üzere King' B besiyerine (KB) (20 g/L Pepton; $1.5 \mathrm{~g} / \mathrm{L}$ $\mathrm{K}_{2} \mathrm{HPO}_{4} ; 1.5 \mathrm{~g} / \mathrm{L} \mathrm{MgSO}_{4} 7 \mathrm{H}_{2} \mathrm{O} ; 10 \mathrm{~mL} / \mathrm{L}$ gliserol; 16 g/L agar, $1 \mathrm{~L}$ saf su; $\left.\mathrm{pH}: 7\right)$ ekilmiştir ve 24-48 saat inkübe edilmiştir. Saflaştırılmış kültürler daha sonra $\% 15$ gliserol katkı1ı $8 \mathrm{~g}$ NB içeren besiyerlerine aşılanmış ve sonraki çalışmalarda kullanılmak üzere $-80^{\circ} \mathrm{C}$ 'de derin dondurucuda saklanmıştır.

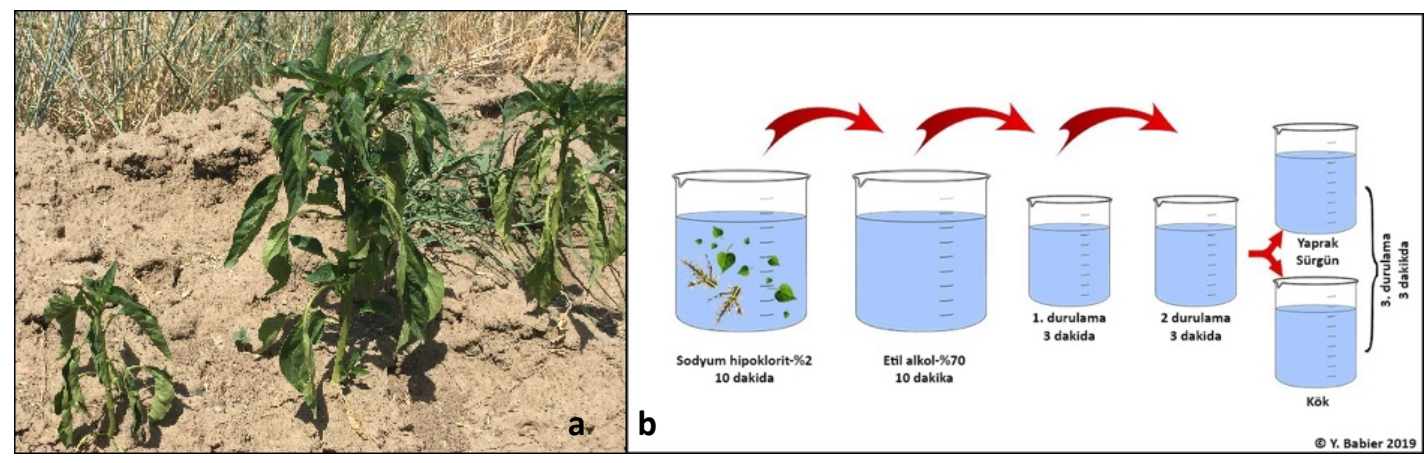


Şekil 1. a) Komşu bitkilere göre pozitif yönde gelişme farklılığı gösteren EB izolasyonu için seçilen bitkiler. b) EB izolasyon çalışmalarında yüzey sterilizasyonu çalışmalarında izlenen yöntem.

\subsection{Endofitik bakterilerin karakterizasyonu}

Aday EB'lerin gram reaksiyonu testleri 48 saatlik kültürler kullanılarak potasyum hidroksit $(\mathrm{KOH})$ testi ile değerlendirilmiştir. İzolatlar tütün yapraklarına enjeksiyon yoluyla uygulanmış ve 48 saat beklenmiştir. Yapraklarda aşırı duyarlılık belirtisine (HR) neden olan örnekler patojen olma ihtimallerine karşı elenmiştir. (Schaad ve ark., 2001).

HR ve gram reaksiyonlarının belirlenmesi ile birlikte, $\mathrm{KB}$ besi yerinde gelişimi, $-80^{\circ} \mathrm{Cde}$ depolanma sonrası hayatlarını sürdürebilme özellikleri belirlenen izolatlar, diğer karakterizasyon testlerine tabi tutulmuştur. Karakterizasyon çalıșması iki aşamalı yürütülmüștür. Birinci aşamada izole edilen ve saflaştırılan endofit bakteri izolatlarının markör PGPR karakterlerinin belirlenmesi, ikinci aşama ise birinci aşama sonuçlarına göre seçilen izolatların bitki patojeni bakterilere karşı antagonistik etkilerinin belirlenmesi şeklindedir.

\subsubsection{Azotu fikse etme yeteneklerinin belirlenmesi}

EB’lerin 24 saatlik saf kültürleri azot içermeyen (N-Free) besiyerine (Döbereiner ve ark., 1972) birbirine eşit uzaklıkta 4 noktaya iğne uçlu öze yardımıyla nokta ekim yoluyla ekilmiş ve 4 gün süreyle 25-27 ${ }^{\circ} \mathrm{C}$ 'de inkübasyona bırakılmıştır. N-Free besiyeri: $10 \mathrm{~g} / \mathrm{L}$ sukroz; $5 \mathrm{~g} / \mathrm{L}$ L-malik asit; $0.1 \mathrm{~g} / \mathrm{L}$ $\mathrm{K}_{2} \mathrm{HPO}_{4} ; 0.4 \mathrm{~g} / \mathrm{L} \mathrm{KH} \mathrm{KH}_{2} \mathrm{PO}_{4} ; 0.2 \mathrm{~g} / \mathrm{L} \mathrm{MgSO}{ }_{4} 7 \mathrm{H}_{2} \mathrm{O} ; 0.01 \mathrm{~g} / \mathrm{L} \mathrm{FeCl} 30.1 \mathrm{~g} / \mathrm{L} \mathrm{NaCl} ; 0.02 \mathrm{~g} / \mathrm{L} \mathrm{CaCl}_{2} 2 \mathrm{H}_{2} \mathrm{O}$; $0.02 \mathrm{~g} / \mathrm{L} \mathrm{Na} \mathrm{MoO}_{4} 2 \mathrm{H}_{2} \mathrm{O} ; 0.05 \mathrm{~g} / \mathrm{L}$ Bromtimol blue (5 ml etil alkolde çözülmüsş) içeren süspansiyonun pH's1 6.9'a ayarlanarak $12 \mathrm{~g} / \mathrm{L}$ agar eklenmiş ve otoklav edilmiştir. Besiyerinde gelişen ve amonyak üretimine bağlı olarak, besiyerinin orijinal rengi olan yeşilden maviye renk değişimine sebep olan izolatların azotu fikse edebilme kabiliyetlerinin var olduğu kabul edilmiştir.

\subsubsection{Fosfatı çözündürme aktivitesinin belirlenmesi}

EB'lerin 24 saatlik saf kültürleri NBRIP Agar besiyerine birbirine eşit uzaklıkta 4 noktaya nokta inokulasyon yoluyla ekilmiştir. NBRIP Agar besiyeri;10 g/L glukoz; 5 g/LCa $\left(\mathrm{PO}_{4}\right)_{2} ; 0.1$ $\mathrm{g} / \mathrm{L}\left(\mathrm{NH}_{4}\right)_{2} \mathrm{SO}_{4} ; 0.2 \mathrm{~g} / \mathrm{LKCl} ; 0.25 \mathrm{~g} / \mathrm{LMgSO}_{4} 7 \mathrm{H}_{2} \mathrm{O} ; 5 \mathrm{~g} / \mathrm{LMgCl}_{2} 6 \mathrm{H}_{2} \mathrm{O}$; ilave edilmiş ortamın pH's1 7'ye ayarlanarak $15 \mathrm{~g} / \mathrm{L}$ agar eklenmiş ve otoklav edilmiştir. İzolatlar 14 gün boyunca $24^{\circ} \mathrm{C}$ 'de inkübasyona bırakılmış ve sürenin sonunda koloni çevresinde oluşan saydam zonlar bakterilerin fosfatı çözündürme aktivitelerinin varlığı olarak değerlendirilmiş ve oluşan zonlar ölçülerek izolatın etkinliği belirlenmiştir (Nautiyal, 1999).

\subsubsection{ACC-deaminaz üretiminin belirlenmesi}

ACC-deaminaz üretim aktivitesi Penrose ve Glick (2003)’in belirttiği yöntemin uyarlanması ile DF besiyeri kullanılarak değerlendirilmiştir. DF besiyeri: $5 \mathrm{mM}(670 \mathrm{mg} / \mathrm{L})$ malik asit; $2 \mathrm{~g} / \mathrm{L}$ glukoz; 2

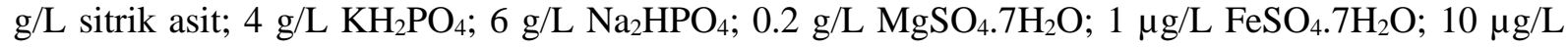
$\mathrm{MnSO}_{4} ; 70 \mu \mathrm{g} / \mathrm{L} \mathrm{ZnSO}_{4} ; 50 \mu \mathrm{g} / \mathrm{L} \mathrm{CuSO}_{4} ; 10 \mu \mathrm{g} / \mathrm{L} \mathrm{MoO}_{3} ; 18 \mu \mathrm{g} / \mathrm{L}$ agar $121^{\circ} \mathrm{C}^{\prime}$ de $20 \mathrm{dk}$. otoklav edilmiş̧ir. Azot kaynağ içermeyen bu ortam negatif kontrol (NK) olarak kullanılmıştır. Pozitif kontrol (PK) için aynı içeriğe $2 \mathrm{~g} / \mathrm{L}\left(\mathrm{NH}_{4}\right)_{2} \mathrm{SO}_{4}$ azot kaynağ 1 eklenmiştir. ACC-deaminaz aktivitesinin belirlenmesi amaciyla azot kaynağ $\left(\left(\mathrm{NH}_{4}\right)_{2} \mathrm{SO}_{4}\right)$ yerine $6 \mathrm{mM}$ steril ACC solüsyonu (filtre edilerek sterilize edilmiş) hazırlanmıș ve bu solüsyondan her bir $\left(\mathrm{NH}_{4}\right)_{2} \mathrm{SO}_{4}$ içermeyen katı besiyeri yüzeyine $100 \mu \mathrm{L}$ yayılmıștır. Petriler, ACC-deaminaz aktivitesinin belirlenmesinde kullanılmak için oda sıcaklığında kurumaya bırakılmışlardır. İzolatların 24 saatlik saf kültürlerinin negatif kontrol, pozitif kontrol ve ACC grubu olarak ayrılan petrilere inokülasyonu çizgi ekim yöntemi ile gerçekleştirilmiştir. Petriler $28^{\circ} \mathrm{C}$ 'de $48-72$ saat boyunca inkübe edilerek koloni gelişimleri gözlemlenmiştir. Test gruplarına ait ve koloni gelişimi gözlenen petrilerden alınan koloniler, tekrar NK, PK ve ACC grubu petrilere ekilmiştir. İkinci aşamada da yalnızca PK ve ACC grubu petrilerde gelişim gösteren izolatların ACC deaminaz üretim yeteneklerinin olduğuna karar verilmiştir. İzolatların gelişim yoğunluğu baz alınarak belirlediğimiz 0-3 skalasına göre (0: gelişim yok, 1: tek ve kesin sınırlarla ayrılan az sayıda koloniler, 
2: koloniler bitişik fakat birbirinden ayırt edilebilir durumda, 3: yoğun gelişim sonucu koloniler tamamen birleşmiş ve ayırt edilemez durumda) skorlanmıştır.

\subsubsection{Indol asetik asit üretme yeteneğinin belirlenmesi}

EB'lerin IAA üretimi Akbari ve ark. (2007)'ın belirttiği yöntemde bazı modifikasyonlar yapılarak L-triptofan (L-TRP) varlığında kolorimetrik olarak incelenmiştir. $50 \mathrm{~mL}$ Nutrient Broth (NB) besiyeri 100 mL'lik erlenlere konarak otoklavda sterilize edilmiş, daha sonra her erlen için daha önce filtrasyon yöntemiyle steril edilmiş $5 \mathrm{~mL}$ L-TRP (\%0.05) ilave edilmiştir. Daha sonra bu karışıma EB izolatlarının 48 saatlik kültürlerinden hazırlanan süspansiyonlarından $\left(\mathrm{OD}_{600 \mathrm{~nm}}: 0.1\right) 100 \mu \mathrm{L}$ eklenmiş ve $26 \pm 2^{\circ} \mathrm{C}^{\prime}$ de, $120 \mathrm{rpm}$ 'de 24 saat inkübasyona bırakılmıştır. Elde edilen sıvı kültür $1000 \mathrm{rpm}$ de 10 dk. santrifüj edilmiş ve oluşan süpernatant alınarak Whatman (No: 2) filtre kağıdından geçirilmiştir. Filtre edilen süpernatanttan $3 \mathrm{~mL}$ alınarak bir tüpe aktarılmış ve üzerine $2 \mathrm{~mL}$ Salkowski ayıracı $(2 \mathrm{~mL}$ $0.5 \mathrm{M} \mathrm{FeCl}_{3}+98 \mathrm{~mL} \% 35$ 'lik $\mathrm{HClO}_{4}$ ) ilave edilmiş ve $30 \mathrm{dk}$. renk oluşumu için beklenmiştir. Süre sonunda spektrofotometrede $535 \mathrm{~nm}$ 'de okuma yapılarak absorbans (Abs) değeri belirlenmiştir. Elde edilen Abs değerlerini $\mu \mathrm{g} / \mathrm{mL}$ 'ye dönüştürmek için 1'den 50'ye kadar farklı ppm düzeylerinde IAA süspansiyonu hazırlanarak ölçümler yapılmış ve excel paket programı ile probit analizi yapılarak bir standart eğri oluşturulmuştur. Oluşturulan kurveye göre izolatların IAA üretimi hesaplanmıştır (Akbari ve ark., 2007; Akköprü, 2012).

\subsubsection{Siderofor etkinliğinin belirlenmesi}

Siderefor aktivitesi, Schwyn ve Neilands (1987)'nin önerdiği Blue-CAS Agar metodunun uyarlanması ile belirlenmiştir (Schwyn ve Neilands, 1987; Louden ve ark., 2011).

Blue-CAS Agar besiyeri:

A. CAS solüsyonu: a) $0.06 \mathrm{~g}$ CAS (Fluka Chemicals) $50 \mathrm{~mL}$ steril distile su $\left(\mathrm{ddH}_{2} \mathrm{O}\right)$ içinde çözülmüştür. b) $0.0027 \mathrm{~g} \mathrm{FeCl}_{3}-6 \mathrm{H}_{2} \mathrm{O} 10 \mathrm{~mL}(10 \mathrm{mM}) \mathrm{HC} 1$ içinde çözülmüsşür. c) $0.073 \mathrm{~g}$ HDTMA 40

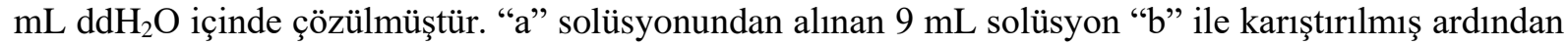
"c" ilave edilmiştir (final solüsyonun koyu mavi renkte olmasına dikkat edilmiştir). Karışım, otoklav işleminden geçirildikten sonra 1şık geçirmeyecek şekilde bir kapta saklanmıştır.

B. Minimal tuz otramı(MM9): $15 \mathrm{~g} \mathrm{KH}_{2} \mathrm{PO}_{4} ; 25 \mathrm{~g} \mathrm{NaCl}$ ve $50 \mathrm{~g} \mathrm{NH}_{4} \mathrm{Cl} 500 \mathrm{ml} \mathrm{ddH}_{2} \mathrm{O}$ içinde çözülmüştür. $20 \mathrm{~g}$ glikoz $100 \mathrm{~mL}$ steril distile su çözündürülmüş filtre ile sterilize edilmiştir.

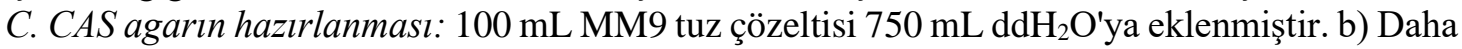
sonra 32.24 g piperazin-N, N'-bis (2-etansülfonik asit) (PIPES) çözülmüștür. Bu amaçla, $\mathrm{NaOH}$ ile $\mathrm{pH}$ 6'ya ayarlanıp karıştırılırken yavaşça PIPES eklenmiştir. PIPES çözündükçe düşen $\mathrm{pH}$ dengelenmiş ve 6.8'e ayarlanmıştır. c) $15 \mathrm{~g}$ agar eklenmiş ve otoklav edilmiştir. d) $50^{\circ} \mathrm{C}$ 'ye soğutulmuş MM9 / PIPES karışımına, $30 \mathrm{~mL}$ steril Casamino asit çözeltisi (3 g Casamino asit $27 \mathrm{~mL}$ steril $\mathrm{ddH}_{2} \mathrm{O}$ ve filtre ile sterilize edilmiştir) ve $10 \mathrm{~mL}$ steril \%20 glikoz çözeltisi ilave edilmiştir. e) Cam duvar boyunca yavaşça 100 mL CAS solüsyon (A) eklenmiş ve karıştırılarak aseptik olarak petri kaplarına dökülmüştür.

Hazırlanan mavi renkli CAS agar besiyerine EB'lerin 24 saatlik saf kültürleri birbirine eşit uzaklıkta bulunan dört noktaya ekilmiş, 7 gün süreyle $24^{\circ} \mathrm{C}$ 'de inkübasyona bırakılmıştır. Koloni çevresinde oluşan ve koloninin bittiği yerden başlayan sarı zonun 4 farklı noktasından ölçülerek aritmetik ortalaması alınmıştır. Elde edilen değerlere göre EB izolatlarının siderofor üretme seviyesi değerlendirilmiştir

\subsection{Tartılı derecelendirme ve antagonizm çalışmaları}

Aday EB izolatları karakterizasyon çalışmalarında gösterdikleri başarıya göre önceden belirlenen ve aşağıdaki formül kullanılarak tartılı derecelendirme puanlamasına (TDP) tabi tutulmuştur (Formül 1). TDP değerine göre ilk 30 adet EB izolatı antagonizm çalışmalarında kullanılmak üzere seçilmiştir.

TDP hesaplaması için her bir karakter için araştırıcılar tarafindan önem derecesine göre belirlenmiş olan bir katsayı verilmiştir. Çalışmamızda katsayılar ACC-d üretimi için 5, fosfat çözündürme yeteneği için 6 , siderofor üretimi için 7 , azot fiksasyon kabiliyeti ve IAA üretimi için 8 olarak belirlenmiştir (Babier, 2019). 
Hesaplama;

- Formülde pay kısmı; her bir karakter için izolatın oluşturduğu değer, aynı karakterde varlık gösteren tüm izolatların ortalamasına (a) bölündükten sonra kategori için belirlenen katsayı ile çarpılarak hesaplanmıştır

- Formüldeki payda kısmı her karakterin en yüksek değeri (b), o karakterin genel ortalamasına (a) bölünerek ve karaktere ait kat sayı ile çarpılarak hesaplanmıştır. Bu şekilde her bir karakter için hesaplanan değerler toplanarak tüm karakterleri temsil eden bir maksimum değere ulaşılmıştır.

- Daha sonra bir izolatın tüm karakterlere ait değerleri toplanmış ve maksimum değere bölünmüştür. Çıkan sonuç 100 ile çarpılmış ve o izolatın TDP değeri hesaplanmıştır (Babier, 2019).

$$
T D P=\left[\frac{5\left(\frac{\mathrm{ACC} *}{a}\right)+6\left(\frac{\mathrm{P}}{a}\right)+7\left(\frac{\mathrm{Sid}}{a}\right)+8\left(\frac{\mathrm{N}}{a}\right)+8\left(\frac{\mathrm{IAA} a}{a}\right)}{\sum\left[5\left(\frac{\mathrm{ACC} b}{a}\right)+6\left(\frac{\mathrm{P} b}{a}\right)+7\left(\frac{\operatorname{Sid} b}{a}\right)+8\left(\frac{\mathrm{N} b}{a}\right)+8\left(\frac{\mathrm{IAA} b}{a}\right)\right]}\right] 100
$$

Formülde; ACC-d: ACC-deaminaz aktivitesini, $P$ : fosfat çözme aktivitesi, Sid: siderofor aktivitesini, $N$ : azot fikse etme kabiliyetini, IAA: indol asetik asit üretme kabiliyetini, *: izolatın o karakterdeki değeri, $a$ : o karakterin izolatları arasındaki ortalaması (aktivite göstermeyenler ortalamaya dahil edilmemiştir), $b$ : o karakterin izolatlar arasında aldığı en yüksek değeri ifade etmektedir.

\subsection{Endofitik bakterilerin bitki patojeni bakterilere karşı in-vitro antagonistik etki testleri}

TDP sonuçlarına göre seçilen en başarılı 30 adet EB izolatının laboratuvar stoklarımızda bulunan bitki patojeni Erwinia amylovora (Ea), Pseudomonas syringae pv. syringae (Pss), P. syringae pv. lachrymans (Psl), P. syringae pv. tomato (Pst), Clavibacter michiganensis sub. sp. michiganensis (Cmm), Xanthomonas axonopodis pv. phaseoli (Xap) ve X. euvesicatoria (Xe)'ya karş1 in-vitro koşullarda antagonistik etkileri araştırılmıştır. Patojen bakterilerin 24 saatlik kültürlerinden hazırlanan $10^{7} \mathrm{CFU} / \mathrm{mL}$ yoğunluğundaki stok süspansiyonlardan $80 \mu \mathrm{L}$ alınarak $7 \mathrm{~cm}$ çaplı petrilerde bulunan $\mathrm{KB}$ besiyerlerinin yüzeyine yayılmış ve kuruması beklenmiştir. Daha sonra 48 saatlik EB kültürlerinden bu petrilere birbirlerine eşit mesafede dört noktaya ekilmiştir. Bu test işlemi her EB-patojen ikilisi için tesadüf parselleri deneme deseninde 3 tekerrürlü olarak yürütülmüştür. Varsa oluşturdukları engelleme zonu (mm) 48 saat sonra ölçülerek in vitro antagonistik etkileri değerlendirilmiştir.

\subsection{Endofitik bakteri izolatlarının moleküler tanılaması}

Karakterizasyon ve antibiyosis çalışmalarında başarılı bulunan EB izolatlarının tanılaması 16s rRNA bölgesinin dizi analizi ile yapılmıştır. Bu amaçla spesifik primerler 27F (5'- AGA GTT TGA TCM TGG CTC AG -3') ve 1492R (5'- TAC GGY TAC CTT GTT ACG ACTT -3’) Baker ve ark. (2003) önerdikleri metot doğrultusunda kullanılmıştır. Yaklaşık $10^{7} \mathrm{CFU} / \mathrm{mL}$ yoğunluğunda hazırlanan bakteri süspansiyonları kuru blok 1sitıcida $10 \mathrm{dk}$. süreyle $95^{\circ} \mathrm{C}$ 'de 1 sitılarak hücrelerin parçalanması sağlanmış, sonrasında oluşan süspansiyonlar 5000 rpm'de $3 \mathrm{dk}$. süre ile santrifüj işleminden geçirilerek hücre kalıntıları uzaklaştırılmıştır. DNA içeren süpernatant PCR reaksiyonlarında kalıp DNA kaynağı olarak kullanılmıştır (Newton, 1995). PCR ürünlerinin değerlendirmesi \%1.5’lik agaroz jelde 100 Volt’ta 30 dakika yürütülerek yapılmıştır. Elde edilen PCR ürünlerinin dizi analizi sonucu tanılama gerçekleştirilmiş̧ir.

\section{Bulgular}

Sörvey çalışmaları sonucu farklı bölgelerden toplam 11 adet biber, 8 adet domates, 5 adet patlıcan, 1 adet nohut, 1 adet fasulye, 3 adet hiyar, 2 adet kabak, 3 adet karpuz, 5 adet kavun, 2 adet salata marul örneği olmak üzere toplam 41 adet örnek toplanmıştır.

Toplanan sağlıklı bitkilerden 191 adet aday EB izolatı elde edilmiştir (Babier, 2019). Bu izolatlardan 11 tanesi tütünde HR oluşumuna neden olmaları veya $-80^{\circ} \mathrm{C}$ 'den çıkarıldıktan sonra tekrar 
canlandırılamadığı için elenmiştir. Geriye kalan 180 adet izolatın \%58.9’unun gram (-), \%41.1'inin gram (+) olduğu tespit edilmiştir (Çizelge 1).

\subsection{Endofitik bakteri izolatlarının karakterizasyonu, tartılı derecelendirilmesi ve antagonistik etkileri}

Karakterizasyon çalışması yapılan 180 adet izolatın her biri azotsuz besiyerine ekilmiştir. Besi yerlerinde koloni gelişimi gözlenmiş fakat hiçbir izolat besiyerlerinde mavi renk dönüşümü gerçekleştirememiştir (Şekil 2a). Ancak bazı bakterilerin besiyerinde yeşilden sarıya bir renk değişimi oluşturduğu gözlenmiştir. Bu durum izolatın $\mathrm{pH}$ değişimine neden olduğu, fakat azot fiksasyonunun gerçekleştiremediği yönünde değerlendirilmiştir. Koloni gelişimi tek başına yeterli olmadığı için 180 adet izolatın hiçbirinin azot fiksasyonu kabiliyetine sahip olmadığına karar verilmiştir.

180 adet izolatın \%20'lik kısmının fosfatı çözme yeteneğine sahip olduğu belirlenmiştir. Bu izolatlardan V33K2 kodlu izolat $11.75 \mathrm{~mm}$ zon oluşturarak fosfotaz aktivitesi gösteren en başarılı izolat olarak saptanmıştır. Fosfataz aktivitesi gösteren 36 adet izolatın 17 tanesinin gram (+), 19 tanesinin gram (-) olduğu belirlenmiş̧tir (Çizelge 1, Şekil 2b).

Tüm izolatların \%13.9’unun ACC-deaminaz aktivitesi gösterdiği belirlenmiştir. 12 adet izolatın gram (+), 13 adet izolatın gram (-) olduğu belirlenmiştir. Şekil 2c'de, besiyerinde gelişim gösteren ve ACC-d aktivitesi bakımından en başarılı izolatlardan biri olan V40K1 izolatı görülmektedir. Çalışma sırasında bazı izolatlar az da olsa gelişim gösterdiği görülmüştür. Bu nedenle ACC-d varlığına karar vermekteki zorluk, gelişim düzeylerinin pozitif ve negatif kontroller ile kıyaslanması ile aşılmıştır (Çizelge 1, Şekil 2c).

Farklı düzeylerde dahi olsa IAA üretim kabiliyetine sahip izolatlar tüm izolatların \%53.3’ünü oluşturduğu belirlenmiştir. IAA üreten 96 adet izolatın 41 adeti gram (+), 55 adeti gram (-) olarak kaydedilmiştir. Aktivite gösteren izolatların 1ppm ile 25 ppm aralığında IAA ürettiği belirlenmiştir. Bu konudaki en başarılı izolat 25.03 ppm IAA üreten V31Y4 kodlu izolat olmuştur. 1 ppm altında IAA üreten izolatların IAA üretimi 0 kabul edilmiştir (Çizelge 1, Şekil 2d).

İzolatların \%75'inin Blue-CAS agar ortamında zon oluşturduğu ortaya konmuştur (Şekil 2e). Siderofor aktivitesi $0.5 \mathrm{~mm}-7 \mathrm{~mm}$ aralığında olan 135 adet izolatın 53 adetinin gram (+), 82 adetinin gram (-) olduğu kaydedilmiştir. Siderefor üretiminde en başarılı izolat $7 \mathrm{~mm}$ ile V40K2 kodlu izolat olmuştur (Çizelge 1)

Yapılan çalışmalar ile markör PGPR karakterleri TDP göre değerlendirilmiştir. Bu tartılı puanlamaya göre en başarılı izolat 51.28 puan ile V31Y4 kodlu izolat olmuştur. TDP ile belirlenen en başarılı 30 adet izolat antagonist etki testlerine alınmıştır (Çizelge 1).

Bitki patojeni yedi adet bitki patojeni bakteriye karşı antagonistik etkilerinin araştırıldığı in vitro çalışmalarda; V30Y3 ve V30G2 kodlu izolatların bütün patojenlere karşı engelleme zonu oluşturduğu gözlenmiştir. V27Y3 izolatı 6 adet patojene; V14G3 izolat1 5 adet patojene; V34G1, V40K1 ve V31K3 kodlu izolatlar 4 adet patojene; V33K2, V37Y1, V40K2 ve V37Y3 kodlu izolatlar 3 adet patojene; V31G1, V41K3, V29Y1 ve V17K2 kodlu izolatlar 2 adet patojene; V32Y2 ve V31K2 kodlu izolatlar 1 adet patojene karşı engelleme zonu oluştururken 13 adet izolat ise hiçbir patojene karşı engelleme zonu oluşturmamıştır. Yalnızca 3 adet izolat Psl ve Pst'ye karşı engelleme zonu oluştururken, 5 adet izolat

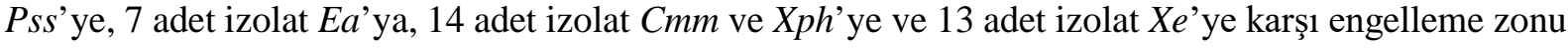
oluşturmuştur (Çizelge 1; Şekil 2f.).

Çizelge 1. Değerlendirilen 180 izolat içinden TDP değeri 10'un üzerinde olan 65 adet aday EB'nin karakterizasyon ve bazı bitki patojeni bakterilere karşı antagonistik etki testi sonuçları.

\begin{tabular}{|c|c|c|c|c|c|c|c|c|c|c|c|c|c|c|}
\hline & \multirow[b]{2}{*}{ İzolat Kodu } & \multirow[b]{2}{*}{$\begin{array}{l}\text { Gram } \\
\text { Reak. }\end{array}$} & \multicolumn{4}{|c|}{ PGPR karakteri * } & \multirow[b]{2}{*}{ TDP } & \multicolumn{7}{|c|}{ Engelleme zonu (mm)** } \\
\hline & & & ACC-d & $\begin{array}{l}\text { Sid. } \\
(\mathrm{mm})\end{array}$ & $\begin{array}{c}\mathrm{P} \\
(\mathrm{mm})\end{array}$ & $\begin{array}{c}\text { IAA } \\
(\mathrm{ppm})\end{array}$ & & Psl & PSS & Pst & $E a$ & $\mathrm{Cmm}$ & $X e$ & Xph \\
\hline 1 & V31Y4 & $(-)$ & 3 & 2.25 & - & 25.03 & 51.28 & - & - & - & - & - & - & - \\
\hline 2 & V33K2 & $(+)$ & - & 1.50 & 11.70 & 7.68 & 47.25 & - & - & - & - & 4.33 & 1.33 & 2.00 \\
\hline 3 & V33K1 & $(+)$ & 1 & 1.75 & 2.58 & 14.32 & 36.38 & - & - & - & - & - & - & - \\
\hline 4 & V37Y1 & $(-)$ & - & 5.5 & 0.75 & 8.56 & 35.98 & - & - & - & - & 7.00 & 2.00 & 2.00 \\
\hline 5 & V40K2 & $(-)$ & 3 & 7.00 & - & 1.38 & 35.22 & - & - & - & - & 1.33 & 2.67 & 2.00 \\
\hline 6 & V31Y3 & $(-)$ & - & 1.63 & 3.17 & 12.21 & 32.36 & - & - & - & - & - & - & - \\
\hline 7 & V35Y1 & $(+)$ & 2 & 1.5 & 2.17 & 10.91 & 31.28 & - & - & - & - & - & - & - \\
\hline 8 & V14G3 & $(+)$ & 3 & 3.00 & - & 9.09 & 30.86 & - & 1.00 & - & 8.00 & 3.00 & 6.00 & 9.00 \\
\hline
\end{tabular}



Belirlenmesi

\begin{tabular}{|c|c|c|c|c|c|c|c|c|c|c|c|c|c|c|}
\hline 9 & V31G1 & $(-)$ & - & 4.50 & 3.42 & 1.79 & 28.99 & - & - & - & - & - & 8.00 & 19.00 \\
\hline 10 & V37G2 & $(-)$ & - & 2.25 & - & 13.5 & 28.58 & - & - & - & - & - & - & - \\
\hline 11 & V41K3 & $(+)$ & 3 & 2.00 & - & 9.74 & 27.89 & - & - & - & - & 3.00 & - & 2.00 \\
\hline 12 & V34G1 & $(+)$ & 3 & 1.00 & 0.50 & 10.97 & 27.07 & - & - & - & 4.00 & 2.00 & 5.33 & 4.33 \\
\hline 13 & V32Y2 & $(+)$ & - & 5.88 & - & 2.62 & 26.82 & - & - & - & - & 1.00 & - & - \\
\hline 14 & V29Y1 & $(+)$ & - & 5.00 & - & 4.32 & 25.90 & - & - & - & - & 4.00 & 3.00 & - \\
\hline 15 & V17G2 & $(-)$ & 3 & 0.50 & 3.84 & 5.09 & 25.05 & - & - & - & - & - & - & - \\
\hline 16 & V32K2 & $(-)$ & 2 & 4.50 & - & 2.03 & 24.45 & - & - & - & - & - & - & - \\
\hline 17 & V30Y3 & $(+)$ & 3 & 1.50 & 1.00 & 6.91 & 24.37 & 2.33 & 2.33 & 2.00 & 2.00 & 9.67 & 8.67 & 16.00 \\
\hline 18 & V36K1 & $(+)$ & - & 1.25 & 6.42 & 1.21 & 23.11 & - & - & - & - & - & - & - \\
\hline 19 & V17K2 & $(+)$ & 3 & 1.75 & - & 7.09 & 23.04 & - & - & - & - & 2.33 & - & 1.00 \\
\hline 20 & V38K1 & $(+)$ & 3 & 1.13 & 1.50 & 5.79 & 22.54 & - & - & - & - & - & - & - \\
\hline 21 & V30G2 & $(-)$ & - & 4.50 & 1.84 & - & 22.31 & 2.00 & 2.00 & 2.00 & 2.00 & 9.67 & 8.33 & 16.00 \\
\hline 22 & V40Y2 & $(-)$ & 3 & 2.00 & - & 5.03 & 21.00 & - & - & - & - & - & - & - \\
\hline 23 & V29Y2 & $(-)$ & - & 2.25 & - & 8.09 & 20.65 & - & - & - & - & - & - & - \\
\hline 24 & V40K1 & $(-)$ & 3 & 1.75 & 2.88 & - & 20.03 & - & - & - & 1.00 & 15.00 & 4.00 & 15.00 \\
\hline 25 & V37Y3 & $(+)$ & - & 2.25 & 2.84 & 2.68 & 20.00 & - & - & - & 4.00 & - & 1.00 & 4.00 \\
\hline 26 & V31K1 & $(-)$ & 3 & - & 1.88 & 6.32 & 19.88 & - & - & - & - & 2.67 & - & - \\
\hline 27 & V27Y3 & $(+)$ & - & 2.00 & 2.25 & 3.26 & 18.38 & 3.00 & 2.00 & 4.00 & 4.33 & - & 4.00 & 8.00 \\
\hline 28 & V31K3 & $(-)$ & - & 2.13 & 2.92 & 1.74 & 18.33 & - & 1.50 & - & - & 15.00 & 6.00 & 15.00 \\
\hline 29 & V31K5 & $(+)$ & 3 & 1.25 & - & 5.09 & 18.15 & - & - & - & - & - & - & - \\
\hline 30 & V17G1 & $(-)$ & 1 & 2.25 & - & 4.68 & 17.59 & - & - & - & - & - & - & - \\
\hline 31 & V8G2 & $(-)$ & - & 1.50 & - & 7.91 & 17.46 & & & & & & & \\
\hline 32 & V41Y3 & $(+)$ & - & 2.00 & 0.75 & 4.74 & 16.69 & & & & & & & \\
\hline 33 & V17K1 & $(-)$ & 2 & 1.00 & 1.00 & 4.32 & 16.68 & & & & & & & \\
\hline 34 & V31Y1 & $(+)$ & - & 0.75 & 2.75 & 4.56 & 16.67 & & & & & & & \\
\hline 35 & V9G2 & $(-)$ & - & 1.50 & - & 7.09 & 16.25 & & & & & & & \\
\hline 36 & V27Y1 & $(-)$ & - & 4.13 & - & - & 16.14 & & & & & & & \\
\hline 37 & V12K2 & $(+)$ & 3 & 0.75 & - & 3.68 & 14.13 & & & & & & & \\
\hline 38 & V36Y2 & $(+)$ & 1 & 1.00 & 2.17 & 1.85 & 14.12 & & & & & & & \\
\hline 39 & V37G1 & $(-)$ & - & 2.50 & 0.50 & 1.91 & 13.86 & & & & & & & \\
\hline 40 & V11K1 & $(+)$ & - & 1.13 & - & 6.38 & 13.75 & & & & & & & \\
\hline 41 & V36K6 & $(-)$ & - & - & 4.50 & 1.26 & 13.39 & & & & & & & \\
\hline 42 & V6Y3 & $(-)$ & - & 2.38 & - & 2.62 & 13.13 & & & & & & & \\
\hline 43 & V18G2 & $(+)$ & - & 1.25 & - & 5.5 & 12.95 & & & & & & & \\
\hline 44 & V2G1 & $(+)$ & - & 1.50 & - & 4.79 & 12.89 & & & & & & & \\
\hline 45 & V7G3 & $(-)$ & - & - & - & 8.74 & 12.80 & & & & & & & \\
\hline 46 & V2K2 & $(-)$ & - & 1.75 & - & 3.97 & 12.66 & & & & & & & \\
\hline 47 & V1G3 & $(-)$ & - & 2.63 & - & 1.62 & 12.64 & & & & & & & \\
\hline 48 & V1G1 & $(-)$ & - & 1.00 & - & 5.91 & 12.57 & & & & & & & \\
\hline 49 & V30G3 & $(-)$ & - & 1.50 & - & 4.56 & 12.55 & & & & & & & \\
\hline 50 & V36G1 & $(-)$ & - & 1.38 & - & 4.74 & 12.32 & & & & & & & \\
\hline 51 & V14Y1 & $(-)$ & 3 & 1.63 & - & - & 12.17 & & & & & & & \\
\hline 52 & V41G2 & $(-)$ & - & 1.75 & - & 3.62 & 12.15 & & & & & & & \\
\hline 53 & V36K3 & $(-)$ & - & 1.00 & 2.00 & 2.09 & 12.10 & & & & & & & \\
\hline 54 & V6K5 & $(+)$ & - & 2.25 & - & 2.21 & 12.03 & & & & & & & \\
\hline 55 & V5K2 & $(+)$ & - & 1.75 & - & 3.38 & 11.80 & & & & & & & \\
\hline 56 & V4G1 & $(-)$ & - & 1.63 & - & 3.56 & 11.57 & & & & & & & \\
\hline 57 & V32G1 & $(-)$ & - & 2.50 & - & 1.21 & 11.55 & & & & & & & \\
\hline 58 & V17K3 & $(-)$ & - & 2.00 & - & 2.38 & 11.32 & & & & & & & \\
\hline 59 & V3G1 & $(-)$ & - & 2.00 & - & 2.21 & 11.06 & & & & & & & \\
\hline 60 & V3Y2 & $(-)$ & 3 & 1.25 & - & - & 10.70 & & & & & & & \\
\hline 61 & V36G3 & $(-)$ & - & 1.63 & - & 2.91 & 10.62 & & & & & & & \\
\hline 62 & V37G3 & $(-)$ & - & 0.50 & - & 5.91 & 10.62 & & & & & & & \\
\hline 63 & V6Y1 & $(+)$ & - & 1.75 & - & 2.56 & 10.60 & & & & & & & \\
\hline 64 & V9G3 & $(-)$ & - & 1.50 & - & 3.15 & 10.48 & & & & & & & \\
\hline 65 & V9Y2 & $(-)$ & - & 1.50 & - & 2.91 & 10.13 & & & & & & & \\
\hline
\end{tabular}

* Çizelgedeki sıralama en yüksek TAD göre yapılmıştır. Çizelgede Gram reaksiyonu (Gram Reak), ACC deaminaz aktivitesi (ACC), Blue-Cas Agar ortamında Siderefor üretim düzeyi (mm) (Sid.), NBRIP Agar besiyerinde fosfat çözme yeteneği (mm) (P), L-TRP'lı ortamda IAA üretimi (ppm) (IAA) olarak belirtilmiştir. Azot fikse eden izolat bulunamadığı için çizelgede verilmemiştir. TAD puanına göre seçilen ilk 30 izolatın çeşitli bitki patojeni bakterilere in vitro da antagonistik etkileri değerlendirilmiştir.

**Patojenlerin kısaltmalar1; Ea: Erwinia amylovora, Pss: Pseudomonas syringae pv. syringae, Psl: Pseudomonas syringae pv. lachrymans, Pst: Pseudomonas syringae pv. tomato, Cmm: Clavibacter michiganensis subsp. michiganensis, Xap: Xanthomonas axonopodis pv. phaseoli, Xe: Xanthomonas euvesicatoria'y1 ifade etmektedir.

Bütün karakterizasyon sonuçları ele alındığında 5 kategorinin hepsinde birden etkinlik gösteren izolat bulunmamıştır. Fakat V33K1, V35Y1, V34G1, V17G2, V30Y3, V38K1, V17K1 ve V36Y2 kodlu EB izolatlarının azot fiksasyonu dışında diğer kategorilerde aktivite gösterdiği tespit edilmiştir. Bunu takiben, 25 adet izolat 3 farklı kategoride, 59 adet izolat 2 farklı kategoride, 67 adet izolat sadece 1 kategoride aktivite gösterirken, 21 adet izolat hiçbir kategoride etkinlik gösterememiştir. 
Karakterizasyon sonuçlarına göre elde edilen TDP'na göre antagonizm testlerine tabi tutulan en başarılı ilk 30 izolatın 15 tanesinin gram (+) ve 15 tanesinin gram (-) olduğu kaydedilmiştir.

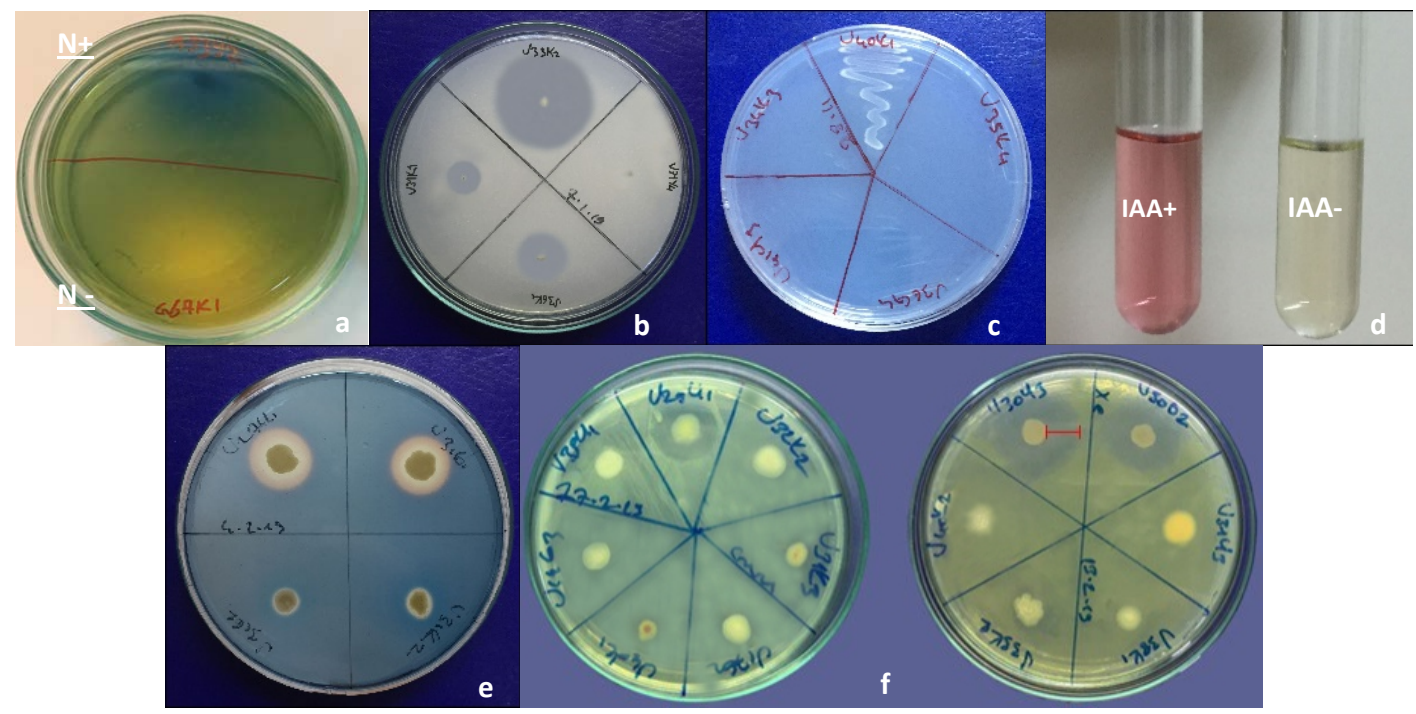

Şekil 2. EB izolatların karakterizasyon testleri. a:Azot fiksasyon testi, b: Fosfat çözme aktivitesi, c: ACC-d aktivitesinin, d: IAA üretimi, e: Siderefor üretimi, f: in-vitro antagonistik etki testleri.

\subsection{Tanılama}

Karakterizasyon ve antagonizm çalışmaları sonucunda seçilen V40K2, V30Y3, V30G2, 31Y4 ve V33K2 kodlu izolatların moleküler tanılaması yapılmış ve NCBI GenBank veri tabanına yüklenerek kabul numaraları alınmıştır. Veri tabanı kullanılarak yapılan karşılaştırmalı veri analiz sonucunda 16s rRNA dizi analizine göre bu izolatlardan V40K2 kodlu izolatın Bacillus velezensis (Acces. Num.:MN186863), V30Y3 kodlu izolatın Bacillus megaterium (Acces. Num.: MN187955), V30G2 kodlu izolatın Pseudomonas caspiana (Acces. Num.: MN128080), V31Y4 kodlu izolatın Pantoea sp. (Acces. Num.: MT249279) ve V33K2 kodlu izolatın Bacillus sp. (Acces. Num.: MT249109) türlerine en yakın olduğu tespit edilmiştir.

\section{Tartışma ve Sonuç}

Son yıllarda yapılan çalışmalar PGPR'ların bitki sağlığına ve gelişimine katkı sağlayan yeni yolaklar veya metabolitler ürettiğini ortaya koymaktadır (Van Loon, 2007; Pieterse ve ark., 2014,). Bitkilerde oluşan etki mekanizmasında bakteri, bitki ve çevre kombinasyonunda hangi faktörün daha belirleyici ve etkili olduğunu tespit etmek çok güçtür. Kesin bulguları ortaya koymak bitki, bakteri ve hedef biyotik veya abiyotik stres koşullarını bir araya getirmek ile mümkün olabilir. En iyimser bakışla, PGPR'ların toprak mikroflorasının yaklaşık \%2-5'ini oluşturabileceği belirtilmiştir (Antoun ve Prévost, 2006). Bu mikroflora içerisinde aranan uygun kombinasyonu bulma şansının daha düşük olacağını söylemek yanlış olmayacaktır. En etkin bakteriyi bulmak için yapılacak bakteri-bitki etkileşim denemeleri çok fazla zaman ve emek gerektirecek bir süreçtir. Bu nedenle belirli karakterlerin in-vitro koşullarda belirlenmesi ve en başarılı izolatların veya aranan karakterlere sahip olanların bitki denemelerine aktarılması sıklıkla başvurulan bir metottur. Genel olarak markör olarak seçilen karakterler; bizim de çalışmamızda seçmiş olduğumuz IAA gibi bitki hormonlarının üretimi, etilen stresini azaltabilen ACC deaminaz üretimi, demir ve fosfor alımında rol oynayan siderofor üretimi ve fosfatı çözme yeteneği gibi özelliklerdir. Ayrıca patojenlere karşı kullanım amacı var ise in-vitro antagonistik testler ön plana çıkmaktadır. In-vitro koşullarda yapılan ön seçimin dezavantajı ise seçilen markör karakterlere sahip olmayan fakat bitkiye bilinen veya bilinmeyen diğer yolak veya metabolitler ile katkı sunabilecek izolatların elenme riskinin olmasıdır. Fakat zaman, işgücü ve maliyet düşünüldüğünde bu dezavantaj genellikle göz ardı edilmektedir. 
Araştırıcılar endofitik ve rizosferik bakterilerin bitki gelişimine ve sağlığına katkı sağlamaları için IAA (Khalid ve ark., 2004) ve ACC deaminaz üretim yeteneklerinin gerekli olabileceğini ve markör olarak kullanılabileceklerini belirtmişlerdir (Etesami ve ark., 2015). Bu özelliklere sahip izolatların, bitkilere kolonizasyon şanslarının daha yüksek olduğu tespit edilmiştir (Etesami ve ark., 2015). Araştırmacılar IAA üretiminin bakterilerin bitkilerle etkileşimlerini sağlayabileceğini (Etesami ve ark., 2015) ve bu bakterilerin bitkide endofit yaşam formuna girmelerinde rolünün olabileceğini bildirmiştir (Verma ve ark., 2001). Gül ve ark. (2013), topraksız tarım yetiştiriciliğinde PGPR uygulaması ile hıyarlarda verim artışı elde etmiş ve bu izolatların in-vitro koşullarda ürettiği IAA düzeyi ile verim artışı arasında önemli düzeyde bir ilişki olduğunu göstermiştir. Bu çalışmalara paralel olarak Akköprü ve Özaktan (2018), yüksek düzeyde IAA üreten P. putida AA11/1'nın farklı hıyar çeşitlerinde \%33-68 oranında verim artışı sağladığını belirlemişlerdir.

Araştırmacılar bitkiler ile birlikte bulunan bakterilerin \%80'inin IAA ürettiğini tahmin etmektedir (Patten ve Glick, 2002; Spaepen ve ark., 2007). Calvo ve ark. (2010), patates rizosferinden elde ettiği 63 izolatın \%81'inin, Ashrafuzzaman et al. (2009), pirinç rizosferinden izole edilen bakterilerin \%60'nın IAA ürettiğini tespit etmiştir. Fakat izolatların ürettiği IAA düzeyi farklılık gösterebilir ve üretim miktarı PGPR etkide önemli bir faktördür. Poonguzhali ve ark. (2008), Brassica campestris rizosferinden izole ettiği PGPR izolatlarının $6.02-27.75 \mathrm{ppm}$ aralığında IAA ürettiğini belirlemiştir. Majeed ve ark. (2015), buğdaydan izole ettiği rhizosferik ve endofitik bakterilerin 0.27 ppm-77.98 ppm aralığında IAA ürettiğini ortaya koymuştur. Yürüttüğümüz çalışma kapsamında izole edilen EB'lerin \%53.3’ünün 1 - 25.03 ppm aralığında IAA ürettiği belirlenmiştir.

Bilindiği gibi, etilen üretimi, stres altındaki bitkilerde artmaktadır, bu da hücre bölünmesini, DNA sentezini ve kök/filiz büyümesi gibi fizyolojik fonksiyonları engellemektedir. PGPR etilenin öncüsü olan ACC’yi ACC-d ile parçalayarak kendisi için azot kaynağı olarak kullanabilir. Bu da bitkide üretimi artan etilenin dengelenmesini sağlayarak olası zararları engeller ve bitki gelişimine yardımcı olur (Glick, 2014). Bu nedenle EB seçiminde ACC-d üretimi önemli bir markördür. Belimov ve ark. (2001), çeşitli toprak örneklerinden izole edilmiş olan ACC-d üretim kabiliyetindeki bakterilerin özellikle olumsuz çevresel koşullar altında bitki gelişimine önemli katkı sunduğunu göstermiştir. Diğer taraftan in-vitro ve moleküler testler ile ACC-d aktivitesi belirlenmiş izolatların normal koşullar ve stres altındaki bitkilerin gelişimini arttırdığ 1 ve bu etkinin ACC-d aktivitesinden kaynaklandığ 1 ortaya konmuştur (Onofre-Lemus ve ark., 2009; Gupta ve Pandey, 2019). Putri ve ark. (2015), incelediği bakteri izolatlarından, kullanılan tekniğe göre değişmekle birlikte, \%17'sinin ACC-d üretme kabiliyetinde olduğunu göstermiştir. Benzer şekilde, çalışmamızda elde ettiğimiz izolatların \%13.9'nün ACC-d üretme yeteneğinde olduğu tespit edilmiştir.

Fosfor noksanlığı tarımsal üretimin temel sınırlayıcı faktörlerinden birisidir (Israr ve ark., 2016). Bitkiler, fosforu ortofosfat anyonları olarak toprak çözeltisinden alırlar. Fakat ortofosfat çok reaktif olduğu için çökelme veya adsorpsiyon yoluyla toprak yapılarına bağlanabilir. Bu da fosfatı çözünmez hale getirir ve bitkiler bu formdan faydalanamaz (Holečková ve ark., 2017). PGPR ürettikleri mikrobiyal metabolitler veya organik asitler ile pH'yı düşürerek kullanılamaz formdaki fosfatı bitki tarafından alınabilir forma dönüştürebilirler (Gupta ve Pandey, 2019). Çetinkaya Yıldız ve Aysan (2014), 39 farklı toprak örneğinden izole ettikleri 499 adet aday PGPR izolatının \%15'inin fosfataz aktivitesine sahip olduğunu bildirmiştir. Benzer birçok çalışma endofit ve rizosferik bakterilerde fosfat çözme aktivitesinin varlığını ortaya koymaktadır (Ahmad ve ark., 2008; Özaktan ve ark., 2015). Fosfat çözme yeteneğinin bakteri cinsleri arasında yaygınlık derecesi farklılık gösterebilmektedir. Çalışmamızdaki EB izolatlarının \%20'sinin farklı düzeylerde de olsa bu yeteneğe sahip olduğu gözlenmiştir. Bu izolatların \%47’sinin gram (+), \%53'ünün gram (-) olduğu belirlenmiştir. Ahmad ve ark., (2008), farklı rizosferik toprak ve bitki kök nodüllerinden izole ettiği 72 PGPR izolatından; Bacillus sp.'ye ait olanların \%80'i, Azotobacter sp.'ye ait olanların \%74.47'si, Pseudomonas sp.'ye ait olanların \%55.56's1 ve Mesorhizobium sp.'ye ait olanların \%16.67'sinin fosfat çözme yeteneğine sahip olduğunu belirlemiştir.

Siderofor üretme yeteneği, mikroorganizmaların ortamdaki diğer mikroorganizmalarla rekabet etmelerinde önemli katkı sağlayan, bitki-bakteri iletişimini kolaylaştıran ve kök kolonizasyonuna yardımcı olan özelliklerden birisidir (Loaces ve ark., 2011). İyi bir siderofor üretim yeteneğine sahip PGPR bakterileri bitki gelişimi ve verimini direkt veya indirekt olarak arttırabilirler. Rizosfer çevresinde çözünmez formdaki demirin alınımını kolaylaştırarak doğrudan veya fitopatojenlerin ihtiyaç duydukları demir için yüksek afiniteli sideroforlarla rekabete girerek gelişimlerini sınırlandırmasıyla dolaylı olarak katk1 sağlayabilirler (Glick, 2015; Kumar ve ark., 2018). Bazı çalışmalar siderofor üretiminin 
bakterilerin bitkinin demir dışında nikel, kurşun veya çinko gibi diğer metaller ile olan etkileşiminde rol oynadığını ve fitoremediasyonda önemli görevler üstlendiğini belirtmişlerdir (Burd ve ark., 2000; Crowley 2000; Kumar ve ark., 2018). Ayrıca siderofor üretiminin bitkinin uyarılmış dayanıklılık sistemini aktive ettiği de bilinmektedir (Van Loon, 2007). Bu nedenle siderofor üretim kabiliyeti PGPR için önemli bir karakterdir. Çalışmamızda toplanan izolatların \%75'inin siderofor üretimine sahip oldukları belirlenmiştir. Siderofor aktivitesi gösteren 135 adet izolatın $0.5-7 \mathrm{~mm}$ aralığında zon oluşturabildikleri tespit edilmiştir. Ahmad ve ark. (2008), yaptıkları çalışmada, inceledikleri izolatlar içerisinde Azotobacter cinsine ait olanların \%12.77'sinin siderofor ürettiğini, bunu sırasıyla Pseudomonas ve Bacillus cinslerinin takip ettiğini ortaya koymuştur. Aynı çalışmada anti fungal aktivitenin de benzer yönde olduğu; Azotobacter izolatlarının \%12.77'sinin, Pseudomonas izolatlarının \%11.11'inin ve Bacillus izolatlarının \%10'unun bu etkiye sahip olduğu belirlenmiştir. Antagonizm çalışmamızda, en az bir patojene karşı engelleme zonu oluşturan 17 adet bakteri izolatı belirlenmiştir. Bunlardan 1 izolat dışında hepsinin siderofor aktivitesi göstermesi dikkat çekicidir. Ahmad ve ark. (2008) ve Priyanka ve ark. (2017), çalışmalarında antifungal etki ile siderofor üretiminin güçlü bir ilişkisi olduğunu bildirmişlerdir. Bununla birlikte antagonistik faaliyetlerden antibiyotikler, toksinler, yüzey aktif bileşikler ve hücre dışı sindirim enzimleri gibi çeşitli mekanizmalar sorumlu olabilir (de Souza ve ark. 2003). Mohamad ve ark. (2018), inceledikleri 114 EB izolatın \%49.1'inin çeşitli bakterilere karş1 $8.6 \mathrm{~mm}$ ile $11.8 \mathrm{~mm}$ arasında zon oluşturarak patojen bakterilerin gelişimlerini sınırladığını belirlemiştir. Arabidopsis thaliana'daki hastalık belirtilerini azaltmada en etkili olan izolatın patojen ile birlikte in-vitro koşullarda geliştirildiğinde antimikrobiyal etkileri olan en az 13 bileşik ürettiği belirlenmiştir. Ayrıca bu izolatların antimikrobiyal bileşikleri kodladığı bilinen poliketid sentaz (PKS) ve ribozomal olmayan protein genlerine sahip olmalarının yanı sıra, kitinazlar, selülazlar, lipazlar ve proteazlar dahil olmak üzere çeşitli hücre dışı sindirim enzimleri ürettikleri de belirlenmiştir.

Karakterizasyon çalışmaları sonucunda en başarılı bulunan beş adet izolatın 16s rRNA bölgesi dizi analizi ile tanılaması yapılmış ve bu ziolatların Bacillus velezensis V40K2 (MN186863), Bacillus megaterium V30Y3 (MN187955), Pseudomonas caspiana V30G2 (MN128080), Pantoea sp. V31Y4 (MT249279) ve Bacillus sp. V33K2 (MT249109) olduğu belirlenmiştir. Birçok çalışma da bu cinslerin PGPR ve biyokontrol özellikleri ortaya konmuştur (Chakraborty ve ark., 2006; Gao ve ark., 2017; Rashid ve ark., 2017; Akköprü ve Özaktan, 2018). Bilindiği üzere bu izolatlar geniş bir ekolojik yelpazede yayılım göstermektedir. Buda onların yüksek adaptasyon yeteneklerinin olduğuna ve tarımsal uygulama bakımında büyük avantajlara sahip olduğunu göstermektedir. Böylece izlenen yolun potansiyeli yüksek, aday PGPR'ın elde edilmesi için uygun olduğu belirlenmiştir.

Sonuç olarak, bu çalışma kapsamında çeşitli kültür bitkilerinden izole edilen endofitik bakterilerin karakterizasyon çalışması sonucunda bitki gelişimine ve sağlığına katkı sağlama potansiyeline sahip bazı EB izolatları tespit edilmiştir. Yapılan moleküler tanılama testlerinden elde ettiğimiz sonuçların mevcut literatür çalışmaları ile karşılaştırılması bu kanıyı güçlendirmiştir. Özellikle Bacillus megaterium V30Y3 ile Pseudomonas caspiana V30G2 izolatlarının çalışmadaki tüm patojenlere karşı antagonistik etki göstermesi ve birçok PGPR belirtecine sahip olması, bunun ile birlikte Bacillus sp. V33K2 (MT249109) ve Pantoea sp. V31Y4 (MT249279) PGPR markör özellikleri bakımından yüksek puan alması hedefler doğrultusunda çeşitli konukçularda bitki sağlığı ve gelişimine katk1 sunma potansiyelinin olduğu görülmektedir. Bu izolatlar ile ileride yapılacak in-vivo denemeler ve tarla çalışmaları ile etkinliklerinin tam olarak ortaya konulabilmesi mümkün olacaktır. Fakat başarı potansiyeli yüksek, nispeten az sayıda izolat ile çalışılacak olması, zaman ve iş gücü tasarrufunun yanı sıra başarı şansını da arttırmış olacaktır.

\section{Kaynakça}

Ahmad, F., Ahmad, I., \& Khan, M. (2008). Screening of free-living rhizospheric bacteria for their multiple plant growth promoting activities. Microbiological Research, 163, 173-181.

Akbari, G. A., Arab, S. M., Alikhani, H. A., Allakdadi, I., \& Arzanesh, M. H. (2007). Isolation and selection of indigenous Azospirillum spp. and the IAA of superior strains effects on wheat roots. World Journal of Agricultural Sciences, 3, 523-529.

Akköprü, A. (2012). Hıyar Bakteriyel Köşeli Yaprak Leke Hastalı̆̆ının (Pseudomonas syringae pv. lachrymans) Bazı Kök Bakterileriyle Biyolojik Savaşımı Üzerinde Araştırmalar. (PhD), Ege Üniversitesi Fen Bilimleri Enstitüsü, İzmir, Türkiye. 
Akköprü, A, \& Özaktan, H. (2018). Identification of rhizobacteria that increase yield and plant tolerance against angular leaf spot disease in cucumber. Plant Protection Science, 54, 67-73.

Antoun, H., \& Prévost, D. (2006). Ecology of Plant Growth Promoting. IN: Z. A. Siddiqui. (Eds) PGPR: Biocontrol and Biofertilization (pp 1-39). Netherlands: Springer.

Ashrafuzzaman, M., Hossen, F. A., Ismail, M. R., Hoque, A., Islam, M. Z., Shahidullah, S. M., \& Meon, S. (2009). Efficiency of plant growth-promoting rhizobacteria (PGPR) for the enhancement of rice growth. African Journal of Biotechnology, 8, 1247-1252.

Azevedo, J. L., Maccheroni Jr, W., Pereira, J. O., \& de Araújo, W. L. (2000). Endophytic microorganisms: a review on insect control and recent advances on tropical plants. Electronic Journal of Biotechnology, 3, 15-16.

Babier, Y. (2019). Van gölü havzasından izole edilen endofit bakterilerin karakterizasyonu ve in vitro koşullarda bazı bitki patojeni bakterilere karşı antagonistik etkilerinin belirlenmesi. (MSc), Van YYÜ, Fen bilimleri Enstitüsü, Van, Türkiye.

Baker, G. C., Smith, J. J., \& Cowan, D. A. (2003). Review and re-analysis of domain-specific $16 \mathrm{~S}$ primers. Journal of Microbiological Methods, 55, 541- 555.

Belimov, A. A., Safronova, V. I., Sergeyeva, T. A., Egorova, T. N., Matveyeva, V. A., Tsyganov, V. E. ,Borisov, A. Y., Tikhonovich, I. A., Kluge. C., Preisfeld, A., Dietz, K. J., \& Stepanok, V. V. (2001). Characterization of plant growth promoting rhizobacteria isolated from polluted soils and containing 1-aminocyclopropane-1-carboxylate deaminase. Canadian Journal of Microbiology, 47, 642-52.

Burd, G. I., Dixon, D. G., \& Glick, B. R. (2000). Plant growth-promoting bacteria that decrease heavy metal toxicity in plants. Canadian Journal of Microbiology, 46, 237-245,

Calvo, P., Ormeño-Orrillo, E., Martínez-Romero, E., \& Zúñiga, D. (2010). Characterization of Bacillus isolates of potato rhizosphere from Andean soils of Peru and their potential PGPR characteristics. Brazilian Journal of Microbiology, 41, 899-906.

Chakraborty, U., Chakraborty, B., \& Basnet, M. (2006). Plant growth promotion and induction of resistance in Camellia sinensis by Bacillus megaterium. Journal of Basic Microbiology, 46, 186195.

Crowley, D. (2000). Function of Siderophores in the Plant Rhizosphere. In: Willig S, Varanin Zi, Nannipieri P.(ed) The Rhizosphere Biochemistry and Organic Substance at the Soil-Plant Interface. CRC Press.

Çetinkaya Yıldız, R., \& Aysan, Y. (2014). Domates bakteriyel solgunluk hastalı̆̆ının bitki büyüme düzenleyici kökbakterileri ile biyolojik mücadelesi. Türkiye Biyolojik Mücadele Der., 5, 9-22.

de Souza, J. T., de Boer, M., de Waard, P., van Beek, T. A., \& Raaijmakers, J. M. (2003). Biochemical, genetic, and zoosporicidal properties of cyclic lipopeptide surfactants produced by Pseudomonas fluorescens. App. Environ. Microbiol., 69, 7161-7172.

Döbereiner, J., Day, J. M., \& Dart, P. J. (1972). Nitrogenase activity and oxygen sensitivity of the Paspalum notatum-Azotobacter paspali association. Microbiology, 71, 103-116.

Etesami, H., Alikhani, H. A., \& Mirseyed Hosseini, H. (2015). Indole-3-Acetic Acid and 1Aminocyclopropane-1-Carboxylate Deaminase: Bacterial Traits Required in Rhizosphere, Rhizoplane and/or Endophytic Competence by Beneficial Bacteria. In: Maheshwari D. (eds) Bacterial Metabolites in Sustainable Agroecosystem. Sustainable Development and Biodiversity, vol 12. (pp.183-258). Springer, Cham

Gao, Z., Zhang, B., Liu, H., Han, J., \& Zhang, Y. (2017). Identification of endophytic Bacillus velezensis ZSY-1 strain and antifungal activity of its volatile compounds against Alternaria solani and Botrytis cinerea. Biological Control, 105, 27-39.

Glick, B. R. (2014). Bacteria with ACC deaminase can promote plant growth and help tofeed the world. Microbiological Research, 169, 30- 39.

Glick, B. R. (2015). Biocontrol mechanisms. In: Glick, B. R. (Eds) Beneficial plant-bacterial interactions (pp. 123-157). Springer, New York.

Gupta, S. \& Pandey, S. (2019). ACC Deaminase Producing Bacteria with Multifarious Plant Growth Promoting Traits Alleviates Salinity Stress in French Bean (Phaseolus vulgaris) Plants. Frontiers in Microbiology, 10, 1506.

Gül, A., Özaktan, H., Kıdoğlu, F., \& Tüzel, Y. (2013): Rhizobacteria promoted yield of cucumber plants grown in perlite under Fusarium wilt stress. Scientia Horticulturae, 153, 22-25. 
Hallmann, J., Quadt-Hallmann, A., Mahaffee, W. F., \& Kloepper, J. W. (1997). Bacterial endophytes in agricultural crops. Canadian Journal of Microbiology, 43, 895-914.

Hardoim, P. R., van Overbeek, L. S., \& van Elsas, J. D. (2008). Properties of bacterial endophytes and their proposed role in plant growth. Trends in Microbiology, 16, 463-471.

Hardoim, P. R. (2011). Bacterial endophytes of rice: their diversity, characteristics and perspectives. $(\mathrm{PhD})$, University of Groningen, Mathematics and Natural Sciences, Netherlands.

Holečková, Z., Kulhánek, M., \& Balík, J. (2017). Use of Active Microorganisms in Crop Production-A Review. Journal of Food Process Technology, 8, 696.

Israr, D., Mustafa, G., Khan, K. S., Shahzad, M., Ahmad N, \& Masood, S. (2016). Interactive effects of phosphorus and Pseudomonas putida on chickpea (Cicer arietinum L.) growth, nutrient uptake, antioxidant enzymes and organic acids exudation. Plant Physiology and Biochemistry, 108, 304312

Khalid, A., Arshad M., \& Zahir Z.A. (2004). Screening plant growth-promoting rhizobacteria for improving growth and yield of wheat. Journal of Applied Microbiology, 96, 473-480.

Kumar, P., Thakur, S., Dhingra, G. K., Singh, A., Pal, M. K. ,Harshvardhan, K. ,Dubey, R. C., \& Maheshwari, D. K. (2018). Inoculation of siderophore producing rhizobacteria and their consortium for growth enhancement of wheat plant. Biocatalysis and Agricultural Biotechnology, 15, 264-269.

Loaces, I., Ferrando, L. \& Fernández Scavino, A. (2011). Dynamics, Diversity and Function of Endophytic Siderophore-Producing Bacteria in Rice. Microbial Ecology, 61, 606-618.

Louden, B. C., Haarmann, D., \& Lynne, A. M. (2011). Use of blue agar CAS assay for siderophore detection. Journal of Microbiology \& Biology Education, 12, 51-53.

Majeed, A., Abbasi, M. K., Hameed, S., Imran, A., \& Rahim, N. (2015). Isolation and characterization of plant growth-promoting rhizobacteria from wheat rhizosphere and their effect on plant growth promotion. Frontiers in Microbiology, 6, 198.

Mercado-Blanco, J., \& Lugtenberg, B. J. J. (2014). Biotechnological Applications of Bacterial Endophytes. Current Biotechnology, 3, 60-75.

Mohamad, O., Li, L., Ma, J. B., Hatab, S., Xu, L., Guo, J. W., Rasulov, B. A., Liu, Y. H., Hedlund, B. P., \& Li, W. J. (2018). Evaluation of the Antimicrobial Activity of Endophytic Bacterial Populations From Chinese Traditional Medicinal Plant Licorice and Characterization of the Bioactive Secondary Metabolites Produced by Bacillus atrophaeus Against Verticillium dahliae. Frontiers in Microbiology, 9, 924.

Nautiyal, C. S. (1999). An efficient microbiological growth medium for screening phosphate solubilizing microorganisms. FEMS Microbiology Letters, 170(1), 265-270.

Newton, C. R. (1995). PCR: Essential data. John Wiley \&amp; Sons, Chichester, UK.

Onofre-Lemus, J., Hernández-Lucas, I., Girard, L., \& Caballero-Mellado, J. (2009). ACC (1Aminocyclopropane-1-Carboxylate) Deaminase Activity, a Widespread Trait in Burkholderia Species, and Its Growth-Promoting Effect on Tomato Plants. Applied and Environmental Microbiology, 75, 6581- 6590.

Özaktan, H., Gül, A., Çakir, B., Yolageldi, L., \& Akköprü, A. (2015). Bakteriyel Endofitlerin Hıyar Yetiştiriciliğinde Biyogübre ve Biyopestisit Olarak Kullanılma Olanaklarl. Tubitak-COST 1110505 no'lu Proje kesin raporu.

Patten, C.L., \& Glick, B. R. (2002). Role of Pseudomonas putida indoleacetic acid in development of the host plant root system, Applied and Environmental Microbiology, 68, 3795-3801.

Penrose, D. M., \& Glick, B. R. (2003). Methods for isolating and characterizing ACC deaminasecontaining plant growth-promoting rhizobacteria. Physiologia Plantarum, 118, 10-15.

Pieterse, C. M. J., Zamioudis, C., Berendsen, R. L., Weller, D. M., Van Wees, S. C. M., \& Bakker P. A. H. M. (2014). Induced systemic resistance by beneficial microbes. Annual Review of Phytopathology, 52, 347-375.

Poonguzhali, S., Madhaiyan, M., \& Sa, T. (2008). Isolation and identification of phosphate solubilizing bacteria from Chinese cabbage and their effect on growth and phosphorus utilization of plants. Journal of Microbiology and Biotechnology, 18, 773-777.

Priyanka, Agrawal, T., Kotasthane, A. S., Kosharia, A., Kushwah, R., Zaidi, N. W., \& Singh, U. S. (2017). Crop specific plant growth promoting effects of ACCd enzyme and siderophore producing and cynogenic fluorescent Pseudomonas. 3 Biotech, 7, 27-38. 
Putri, A. Z., Sasongko, D., \& Susilowati, D. N. (2015). Screening of rhizosphere bacteria from rice fields in the coastal area as ACC-deaminase and auxin producer. International Journal on Advanced Science, 5, 27-30.

Rashid, M., Khan, A., Hossain, M. T., \& Chung, Y. R. (2017). Induction of systemic resistance against aphids by endophytic Bacillus velezensis YC7010 via expressing PHYTOALEXIN DEFICIENT4 in arabidopsis. Frontiers in Plant Science, 8, 211.

Rosenblueth, M., \& Martínez-Romero, E. (2006). Bacterial endophytes and their interactions with hosts. Molecular Plant-Microbe Interactions, 19, 827-837.

Ryan, R. P., Germaine, K., Franks, A., Ryan, D. J., \& Dowling, D. N. (2008). Bacterial endophytes: recent developments and applications. FEMS Microbiology Letters, 278, 1-9.

Saharan, B., \& Nehra, V. (2011). Plant growth promoting rhizobacteria: a critical review. Life Sciences and Medicine Research, 2011, 1-30.

Schaad, N. W., Jones, J. B., \& Chun, W. (2001). Laboratory Guide for the Identification of Plant Pathogenic Bacteria. American Phytopathological Society, USA.

Schwyn, B., \& Neilands, J. B. (1987). Universal chemical assay for the detection and determination of siderophores. Analytical Biochemistry, 160, 47-56.

Spaepen, S., Vanderleyden, J., \& Remans, R. (2007). Indole-3-acetic acid in microbial and microorganism-plant signaling. FEMS Microbiology Reviews, 31, 425-448.

Surette, M. A., Sturz, A. V., Lada, R. R., \& Nowak, J. (2003). Bacterial endophytes in processing carrots (Daucus carota L. var. sativus): their localization, population density, biodiversity and their effects on plant growth. Plant and Soil, 253, 381-390.

Turhan, Ş. (2005). Tarımda sürdürülebilirlik ve organik tarım. Tarım Ekonomisi Dergisi, 11, 13-24.

Van Loon, L. C. (2007). Plant responses to plant gowthpromoting rhizobacteria. European Journal of Plant Pathology, 119, 243-254.

Verma, S. C. Ladha, J. K., \& Tripathi, A. K. (2001). Evaluation of plant growth promoting and colonization ability of endophytic diazotrophs from deep water rice. Journal of Biotechnology, $91,127-141$ 